\title{
Article
}

\section{Development of Mechanical Measurement Technique for Planar Elongation Viscosity Using Resistant Force on Pushing Bullet Bob}

\author{
Yukinobu SUGIHARA*, Wataru KUBOTA ${ }^{* * *}$, Yumiko YoshitaKE* ${ }^{* *}$, Tsutomu TAKAHASHI ${ }^{* *, \dagger}$, \\ Shuichi IWATA ${ }^{* * *}$, Ryo NAGUMO ${ }^{* * *}$, and Hideki MORI ${ }^{* * *}$ \\ *Department of Energy and Environment Science, Graduate School of Nagaoka University of Technology \\ 1608-1 Kamitomioka, Nagaoka, Niigata 940-2188, Japan \\ ${ }^{* *}$ Department of Mechanical Engineering, Nagaoka University of Technology \\ 1608-1 Kamitomioka, Nagaoka, Niigata 940-2188, Japan \\ ${ }^{* * *}$ Department of Materials Science and Engineering, Nagoya Institute of Technology \\ Gikiso-cho, Showa-ku, Nagoya, Aichi 466-8555, Japan
}

\begin{abstract}
A noble measurement method for planar elongation viscosity was proposed. A bullet shaped bob was pushed into a sample liquid held in a cylindrical cup with a constant velocity and the resistance force acting on the bullet bob was measured. The bullet bob was designed to generate steady planar elongation flow through the gap between the bob and the cup. The trial experiments were carried out for standard viscous fluids and aqueous polymer solutions. The resistant forces were measured as a function of the planar elongation rate. The forces were compared to flow analysis of Newtonian, non-Newtonian and viscoelastic fluids. These forces were generally consistent with experimental data.

Key Words: Planar elongation viscosity / Rheometry / Bullet bob / Finite element analysis
\end{abstract}

\section{砲弾ボブの押し込み反力による 平面伸張粘度の機械的測定手法の開発}

杉原 幸信 ${ }^{*}$, 久保田 航 ${ }^{* * *}$, 吉武 裕美子 ${ }^{* *}$, 高橋 勉 ${ }^{* *}$, 岩田 修一 ${ }^{* * *}$, 南雲 亮 $^{* * *}$, 森 秀樹 ${ }^{* * *}$

（原稿受理：2016 年 2 月 9 日）

\section{1. 緒言}

液晶ディスプレイの大画面化，高機能化に伴い偏光特性 や複屈折特性を有する機能性光学フィルムの需要が高まっ ている.これらのフィルムの品質は画質に直接影響するた め厚さや光学特性などが高度に制御される必要がある。フィ ルム成形やブロー成形では高分子材料の平面伸張変形特性, すなわち, 平面伸張粘度が生産性や品質に大きな影響を及ほ している。 ニュートン流体では平面伸張粘度の值はせん断 粘度の 4 倍となるが, 粘弾性特性を示す高分子材料ではこ の関係が成り立たず，かつ平面伸張粘度は平面伸張速度の

\footnotetext{
* 長岡技術科学大学大学院 工学系研究科 エネルギー・環境工学専攻 $\overline{\mathrm{T}}$ 940-2188 新潟県長岡市上富岡町 1603-1

** 長岡技術科学大学大学院 技学研究院 機械創造工学専攻

₹ 940-2188 新潟県長岡市上富岡町 1603-1

*** 名古屋工業大学大学院 工学研究科物質工学専攻

$\bar{T} 466-8555$ 愛知県名古屋市昭和区御器所町

$\dagger$ ttaka@nagaokaut.ac.jp
}

関数となる.このため, 平面伸張粘度の值を求めるためには, 平面伸張速度と平面伸張応力の関係を実験により明らかに する必要がある。

伸張粘度には一軸伸張粘度, 二軸伸張粘度㧍よび平面伸 張粘度がある. 円柱状の試験片の両端を掴んで細長く引き 延ばすことにより，比較的簡単に一軸伸張変形を形成する ことができる，一方，平面伸張変形を形成するためには幅 を一定に保った状態で引き延ばす必要がある。また，引っ 張り変形で定常伸張流動状態を形成するには引っ張り速度 を指数関数的に増加する必要がある．掴むことができない 低粘度の溶融液などの液体に対して伸張速度が一定となる 定常伸張流動場を作り出すことはさらに難しい. Macoskoら 抢よび Kelly と Graessley ${ }^{2}$ は二次元対向噴流型の流路により, よどみ線上で定常平面伸張流動状態を形成した。 Shirakashi ら ${ }^{3)}$ は Hele-Shaw Cell を用いた急縮小流れの流入部の流線形 状から平面伸張応力を評価する方法を提案した。 Pendse と Collier ${ }^{4)}$ は二次元縮小流路により平面伸張流動場を形成し, 圧力損失から平面伸張応力を推定することで平面伸張粘度 
を評価した. しかし, 曲率を有する壁面に設置した圧力孔 で測定した圧力の正当性や伸張応力を導くための仮定の妥 当性に問題があった. Takahashi ら $^{5)}$ は同様な二次元縮小流 路において平面伸張応力を流動複屈折により求めた。 また, 加藤らは4-ロールミル型流路 ${ }^{6}$ および平面スクイーズ流路 ${ }^{7}$ を用いて定常平面伸張流動状態を形成し, よどみ線上の流動 複屈折から平面伸張応力を求めた. 流動複屈折から応力を 算出する方法は光弾性則が成立する透明な試料に対しては 有効であり, 光学測定のため流れ場に影響を与えず測定で きて, かつ多点測定により応力分布を求めることもできる. しかし, 適用できる試料が限られるため汎用性は低い.

本研究では, 汎用性の高い平面伸張粘度の測定技術の開 発をめざす。平面伸張流動場の形成には Fig. 1(a)に示す二次 元縮小流路を検討する。ただ, この二次元縮小流路では壁 面摩擦の効果を低減するために, 奥行き方向 (Fig. 1(a)では 紙面に垂直方向）の厚さを流路幅に対して十分に大きく取る 必要があり, 定常流動場を作り出すためには大量の試料が必 要となる. そこで, Fig. 1(b)に示すように砲弾型のボブと円 筒型のカップとの側面によって構成される環状縮小流路を 提案する. 環状縮小流路においては, 砲弾ボブと円筒型カッ プの間の隙間がボブの半径に比べて十分に小さければ軸対 称な二次元流動場と見なすことができる。 また，Fig. 1(a)の 二次元縮小流路における紙面に垂直方向の上下平面に相当 する壁面が存在しないため, より正確な平面伸張流動を発 生させることができる.さらに, 円筒型カップ内に試料を 満たしておき，その中に砲弾ボブを押し込むことでボブの 押し込みにより排除される流体が側面の隙間を通って上部 に移動する。すなわち, 流れ場を保持するためのポンプな どが不要であり, かつ, 押し込み速度を変えることで流量, 平面伸張速度を容易に制御できる。余計な流動発生装置が 不要なため計測に必要な試料の量も少ない.さらに, 実験 のプラットフォームとして市販のレオメータを使用するこ とで, 押し込み速度を制御しつつボブに作用する押し込み 反力を同時に求めることができる. ボブに作用する押し込 み反力には, ボブ側面を通る流れによって発生する平面伸 張応力の効果が含まれるため, その他の原因による反力の 大きさを考慮することで平面伸張応力の大きさを見積もる ことができる。

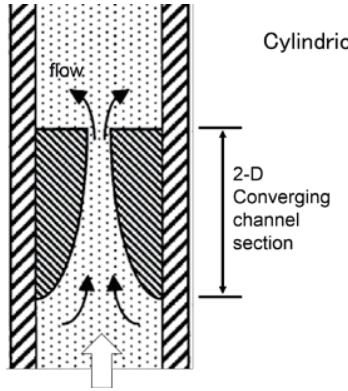

(a) Two-dimensional converging channel

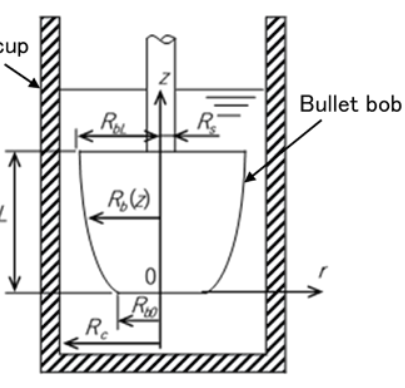
converging channel (b) Two-dimensional annular

Fig. 1. Flow cells to generate steady planar elongation flow for mechanical measurement method.
この砲弾ボブによる新たな平面伸張粘度測定技術につい て，本報告ではニュートン流体および粘弾性流体を用いて 試験的な計測を行い，押し込み速度とボブに作用する押し 达み反力の関係を求める。簡易的な解析により，押し込み 反力から平面伸張応力を見積もる方法を検討し, 平面伸張 粘度を算出する。ささらに，数值解析により砲弾ボブのまわ りの流れ場を計算し，この手法の正当性について検討する.

\section{2. 砲弾ボブの形状および数值解析の条件}

\section{1 砲弾ボブの押し込みによる平面伸張流動場の形成}

Fig. 1(b)に砲弾ボブの座標系を示す。砲弾ボブ底面の中心 を原点とし, 砲弾ボブの半径方向を $r$ 座標, 高さ方向を $z$ 座 標とする円筒座標系を用いた。砲弾ボブの側面形状 $R_{b}(z)$ は, カップ内面との隙間を通過する試料の平面伸張速度が一定 となるように決定される，狭い隙間であるため壁面摩擦の 効果が大きいが, 本研究の第一段階として壁面での摩擦を 無視し, 断面平均流速 $\bar{v}(z)$ が流動方向に比例して増加する形 状を考える。 $\bar{v}(z)$ は式 (1)で示される.

$$
\bar{v}(z)=\dot{\varepsilon}_{P E} z+\bar{v}_{0}
$$

ここに， $\dot{\varepsilon}_{P E}$ は隙間を通過する試料の平面伸張速度， $\bar{v}_{0}$ は隙 間の入口 $(z=0)$ における平均流入速度である. 隙間には砲 弾ボブの移動によって排除された流体が流入する。しかし, この段階では砲弾ボブの形状が決定していないため, 円筒 型カップの底面から砲弾ボブの押し込み速度 $V_{b}$ と等しい流 速の一様流が流れ込むと仮定して式 (2)により $\bar{v}_{0}$ を求める.

$$
\bar{v}_{0}=\frac{R_{c}^{2}}{R_{c}{ }^{2}-R_{b 0}^{2}} V_{b}
$$

隙間入口と隙間内の任意断面において連続の式を考えるこ とにより， $R_{b}(\mathrm{z})$ は式 (3)で表される.

$$
R_{b}(z)=\sqrt{R_{c}{ }^{2}-\frac{\left(R_{c}{ }^{2}-R_{b 0}{ }^{2}\right) R_{c}{ }^{2}}{e\left(R_{c}{ }^{2}-R_{b 0}{ }^{2}\right) z+R_{c}{ }^{2}}}
$$

ここに, 式中の伸張速度係数 $e$ は, $\dot{\varepsilon}_{P E}$ とボブの押し込み速 度 $V_{b}$ を関係付ける比例定数と定義する.

$$
\dot{\varepsilon}_{P E}=e V_{b}
$$

\section{2 数值解析に用いる支配方程式と境界条件}

砲弾ボブの平面伸張流動場の粘弾性解析を並行して行い, 本測定手法の特性について検討する. 非圧縮性流体の等温定 常流れにおける連続の式と運動方程式をそれぞれ式 (5), 式 (6)に示す.

$$
\nabla \cdot v=0
$$

$$
\rho \boldsymbol{v} \cdot \nabla \boldsymbol{v}+\nabla p-\nabla \cdot \boldsymbol{\tau}-\rho \boldsymbol{g}=\mathbf{0}
$$

ここに, $\boldsymbol{v}$ は速度ベクトル, $\tau$ は異方性応力テンソル, $p$ は圧力, $\rho$ は密度, $\boldsymbol{g}$ は重力加速度べクトルである。 ニュー トン流体ならびに非ニュートン流体の構成方程式には式 (7) を用いた。. 式中の粘度 $\eta$ については, 式 (8)の Carreau Yasuda モデル ${ }^{8)}$ を用いた。 


$$
\tau=2 \eta S
$$

$$
\eta=\eta_{0}\left[1+(\lambda \dot{\gamma})^{a}\right]^{-d / a}
$$

ここに, $\dot{\gamma}$ はせん断速度, $\lambda$ は緩和時間, $d$ はべき乗則に おける傾き, $a$ はパラメー夕值である，S $\boldsymbol{S}$ は変形速度テンソ ルであり，次式により定義される.

$$
\boldsymbol{S} \equiv\left[\nabla \boldsymbol{v}+(\nabla \boldsymbol{v})^{\mathrm{T}}\right] / 2
$$

粘弾性流動解析では, 単一モード Giesekus モデル ${ }^{9)}$ 式 (10), 式(11)をそれぞれ用いた。

$$
\begin{aligned}
& \boldsymbol{\tau}=2 \eta_{0} s \boldsymbol{S}+\boldsymbol{E} \\
& \boldsymbol{E}+\lambda \stackrel{\nabla}{\boldsymbol{E}}+(\alpha / G) \boldsymbol{E}^{2}=2 \eta_{0}(1-s) \boldsymbol{S}
\end{aligned}
$$

ここに, $\boldsymbol{E}$ は弾性応力テンソル, $\boldsymbol{E}$ は式 (12) に示す反変型対 流微分である， $\eta_{0}$ はゼロせん断粘度， $G$ は緩和弾性率， $\alpha$ と $s$ はモデルパラメータである.

$$
\stackrel{\nabla}{\boldsymbol{E}} \equiv \frac{\partial \boldsymbol{E}}{\partial t}+\boldsymbol{v} \cdot \nabla \boldsymbol{E}-\left[(\nabla \boldsymbol{v})^{\mathrm{T}} \cdot \boldsymbol{E}+\boldsymbol{E} \cdot \nabla \boldsymbol{v}\right]
$$

Fig. 2(a)に境界条件を示す。カップとボブの中心軸には軸 対称条件を与えた，実験系では砲弾ボブを試料の入ったカッ プに押し込むことで流れ場を得ている. 一方, 解析では砲 弾ボブとカップを静止させ, カップの底面を流路入口とし て完全発達流れをボブの押し込み速度 $V_{b}$ と一致する平均流 速で与えた。 また，出口では入口と同じ流量だけ流出する よう設定した。粘弾性流動解析における Solverには, Ansys Polyflow v.16.1 を用い, 構成方程式には EVSS 法 ${ }^{10)}$ を用いた。 速度と変形速度には双二次要素を, 圧力には双一次要素を, 応力場には $4 \times 4$ サブエレメント法 ${ }^{11)}$ を用いた。 二次元流路 出口のカップ側の点でのゲージ圧力を $0 \mathrm{~Pa}$ と与え, 反復解 法により解を求めた。 ボブ近傍の要素分割を Fig.2(b)に示す. ボブとカップの間の領域は半径方向に 20 分割した。次に, 砲弾ボブにかかる反力は式 (13), (14)を用いて求めた.

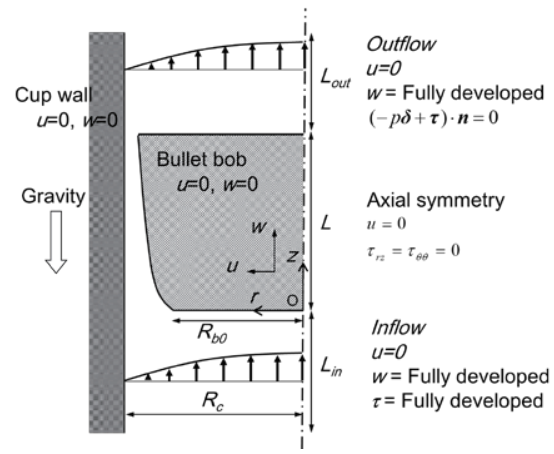

(a) Boundary conditions

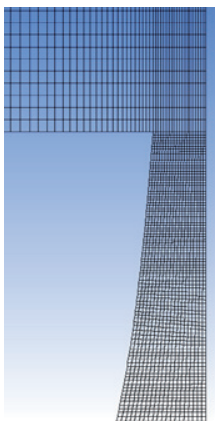

(b) Mesh profile
Fig. 2. Boundary conditions and mesh profile of numerical simulation.

$$
\begin{aligned}
& F_{N}=\left.P A\right|_{z=0}-\left.P A\right|_{z=L}+F_{\text {side }} \\
& F_{\text {side }}=\int_{0}^{z} \int_{0}^{2 \pi}\left[(\boldsymbol{T} \cdot \boldsymbol{n}) \cdot \boldsymbol{e}_{z}\right] R_{b}(z) \sqrt{1+R_{b}(z)} d \theta d z
\end{aligned}
$$

ここに, $\boldsymbol{T}(=-p \boldsymbol{\delta}+\boldsymbol{\tau})$ は全応力テンソル, $\boldsymbol{n}$ はボブ表面に おける単位法線ベクトルである。 ボブ側面に作用する反力 $F_{\text {side }}$ は微小反力をボブ側面に渡って積分することにより求め た. また, $V_{b}=0 \mathrm{~mm} / \mathrm{s}$ で計算を行い, その計算結果を $V_{b} \neq$ $0 \mathrm{~mm} / \mathrm{s}$ の結果から差し引くことにより浮力の補正を行った.

\section{3. 実験装置および試料}

\section{1 測定に使用したプラットフォーム}

本測定手法では砲弾ボブを円筒型カップに同心状態を 保って一定速度で押し込み, 同時に押し込み反力を測定する 必要がある. そのため, これらの機能を基本機能として備え ている TA Instruments 社製ひずみ制御型レオメータ ARES-LS を測定のプラットフォームとして利用した。 円筒型カップは レオメータに付属の同心二重円筒型流路のカップ(内半径 8.5 $\mathrm{mm}$ ）を流用した，また，砲弾ボブは $V_{b}=1.0 \mathrm{~mm} / \mathrm{s}$ のときに $\dot{\varepsilon}_{P E}=0.75,1.0 \mathrm{~s}^{-1}$ となる二種類のボブを使用した. 式(4)より, これらは名称にあたる伸張速度係数 $e$ に $V_{b}$ をかけることで 隙間内に生じる平面伸張速度を算出できる。使用した砲弾 ボブおよび円筒型カップの諸元を Table I に示す.

\section{2 試料}

実験および数值解析には，ニュートン流体として粘度計 校正用標準液であるJS2000 $\left(\eta=1.313 \mathrm{~Pa} \cdot \mathrm{s}, \quad \rho=850 \mathrm{~kg} / \mathrm{m}^{3}\right)$ を用いた。また，粘弾性流体には水溶性高分子ポリアクリ ルアミド $(\mathrm{PAA})$ をイオン交換水に $0.2 \mathrm{wt} \%$ の割合で溶かし たPAA0.2 wt \% 水溶液 $\left(\rho=1026 \mathrm{~kg} / \mathrm{m}^{3}\right)$ を使用した. Fig. 3 にPAA0.2 wt $\%$ 水溶液のレオロジー特性と Carreau-Yasuda, Giesekus モデルによる相関の結果を示す. 実験は $23 \sim 25{ }^{\circ} \mathrm{C}$ で行った。

\section{4. 実験結果および考察}

\section{1 砲弾ボブの押し込みによる反力の測定結果}

Fig. 4 は試料液面下に没した状態の砲弾ボブをステップ 状に一定速度で降下させ, さらに一定時間後に停止させた ときの押し込み反力 $F$ の時間的変化を示している。試料は JS2000 である。流動開始前の状態を統一するために砲弾ボ

Table I. Dimensions of bullet bob.

\begin{tabular}{|l||c|c|}
\hline Bullet bob & $\mathrm{e}=0.75, \mathrm{~L}=9.3$ & $\mathrm{e}=1.0, \mathrm{~L}=7.0$ \\
\hline \hline$\varepsilon_{P E}$ at $V_{b}=1.0 \mathrm{~mm} / \mathrm{s}$ & $0.75 \mathrm{~s}^{-1}$ & $1.0 \mathrm{~s}^{-1}$ \\
\hline Maximum radius $R_{b L}$ & \multicolumn{2}{|c|}{$8.00 \mathrm{~mm}$} \\
\hline Minimum radius $R_{b 0}$ & $5.50 \mathrm{~mm}$ & $5.50 \mathrm{~mm}$ \\
\hline Length $L$ & $9.30 \mathrm{~mm}$ & $7.00 \mathrm{~mm}$ \\
\hline Cup radius $R_{c}$ & \multicolumn{2}{|c|}{$8.50 \mathrm{~mm}$} \\
\hline
\end{tabular}


ブの上面が試料液面より下となる位置まで押し达み，その 後一定時間静止させてから測定を開始した。ボブを一定速 度で降下させている過程では，ボブを支える中心軸が試料 中に押し込まれていくため浮力 $F_{b}$ が増加し， $F$ は直線的に 大きくなる。この状態からボブを停止すると $F$ は低下し， $F_{b}$ に相当する值を示して一定となる。式 (15)により $F_{b}$ は幾何 学的に算出することができ，この值を $F$ から引くことで流 動により発生する押し込み反力 $F^{\prime}$ （浮力の増加分が補正さ れた值）を得る。

$$
F_{b}=\rho g \pi R_{s}{ }^{2}\left(1+\frac{R_{s}{ }^{2}}{R_{c}{ }^{2}-R_{s}{ }^{2}}\right) V_{b} t
$$

Fig. 5 に示す JS2000 の場合, 浮力の効果を補正した $F^{\prime}$ は 押し込み過程で一定の值を保ち, 押し込み停止と同時にゼロ に戻る. Fig. 6 は, 粘弾性流体である PAA $0.2 \mathrm{wt} \%$ 水溶液に 対して Fig. 5 と同様の実験を行った結果である. ステップ単

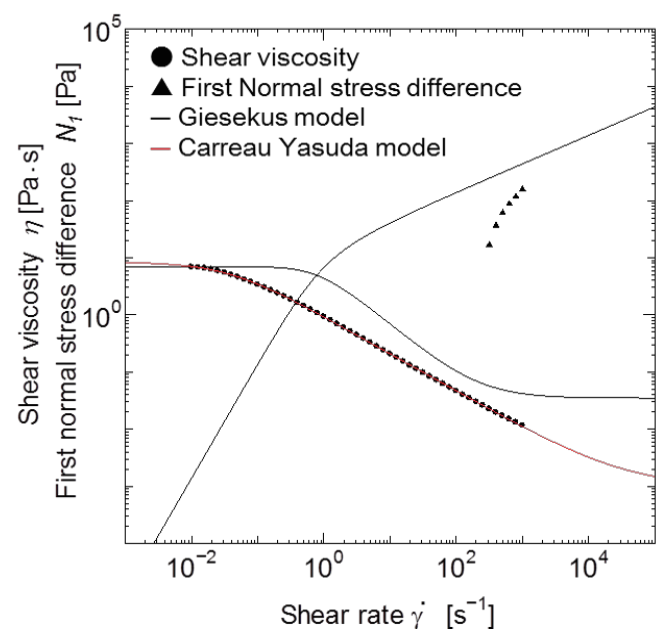

Fig. 3. Rheological property of PAA0.2 wt $\%$ aqueous solution. Red line is correlation of Carreau-Yasuda model. Black line is correlation of Giesekus model.

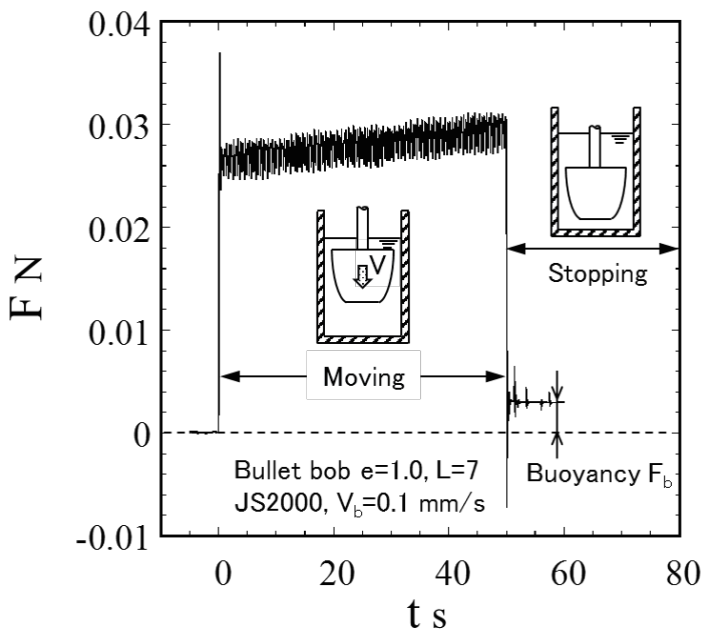

Fig. 4. Resistant force $F$ acting on bullet bob.
純せん断流れと同様に流動開始直後に $F^{\prime}$ がオーバーシュー トする挙動がみられ，時間経過に伴い $F$ ’が増加することが わかる。押し込み停止後の F'はJS2000 と異なり, 徐々にゼ ロに戻ることがわかる。これはPAA $0.2 \mathrm{wt} \%$ 水溶液の緩和時 間に依存した挙動と考えられる。また， Fig. 5 および Fig. 6 に見られる押し込み反力の周期的な振動は，砲弾ボブを移 動させるモー夕の駆動による影響と推測される。さらに, $\mathrm{JS} 2000$ とAA0.2 wt \% 水溶液で振動の振幅に約 10 倍の差が あることがわかる。 $V_{b}=0.1 \mathrm{~mm} / \mathrm{s}$ におけるボブ壁面せん断 速度を概算してそれぞれの試料のせん断粘度を比較すると， PAA0.2 $\mathrm{wt} \%$ 水溶液のせん断粘度はJS2000の約 $10^{-1}$ 倍となる. したがって，それぞれの試料における振幅の差は，せん断 粘度の大きさの違いによるものであると考えられる.

これらの実験結果よりオーバーシュート領域を除いた流 動中における $F^{\prime}$ の平均值と $\dot{\varepsilon}_{P E}$ の関係を調べた。ここで, 振動の周期に対して十分に広い範囲の $F^{\prime}$ の平均值を用いる ことにより振動による值の変化が測定に影響しないように

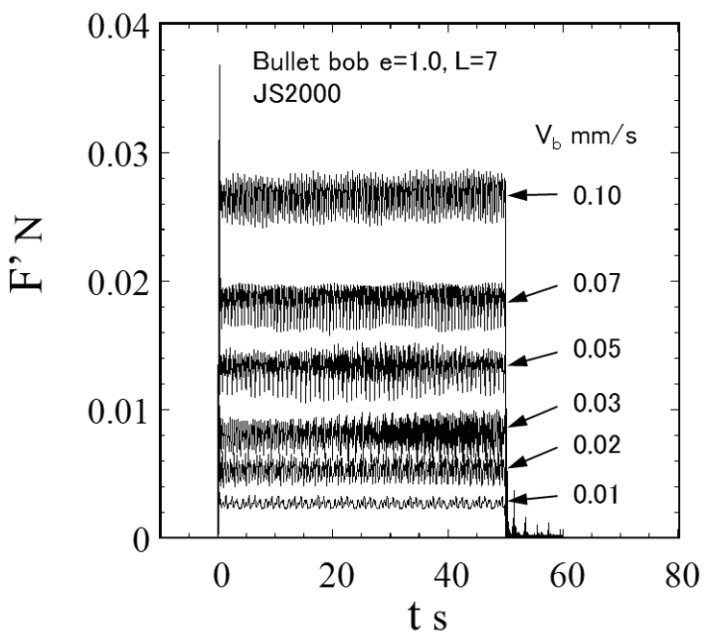

Fig. 5. Buoyancy corrected resistant force $F^{\prime}$ for JS2000.

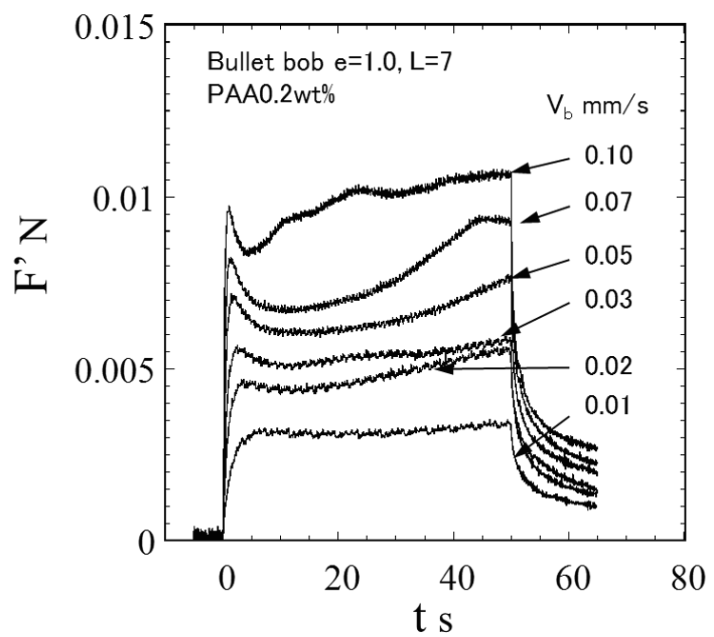

Fig. 6. Buoyancy corrected resistant force $F^{\prime}$ for PAA0.2 wt\% aqueous solution. 
している. Fig. 7 より, JS2000の $F^{\prime}$ は $\dot{\varepsilon}_{P E}$ の 1 次関数で表 されることがわかる。ニュートン流体では，せん断粘度と 平面伸張粘度が変形速度に依存しない定数であることから, $\dot{\varepsilon}_{P E}$ と $F^{\prime}$ の比例関係は予想される結果と一致する。一方, PAA0.2 wt\% 水溶液の結果は $\dot{\varepsilon}_{P E}$ の増加に対して $F^{\prime}$ の増加率 が減少しており, ずり流動化と同様の挙動を示している。 ま た, 同じ $\dot{\varepsilon}_{P E}$ でも砲弾ボブ $e=0.75$ の方が大きな值となるこ とがわかる. 砲弾ボブ $e=0.75$ は $e=1$ よりもボブが長いため, せん断流れによる反力が大きくなったことが考えられる。

\section{2 数値解析結果との比較}

JS2000 の数值解析による $F^{\prime}$ を Fig. 8 に示す. 図中の白抜 き記号は実験によって求めた值, 塗り潰し記号は数值解析に よって求めた值を意味する。この図から計算值と実験值の 定性的傾向は一致していることがわかり，今回の計算にお ける境界条件の設定, および, 反力の計算方法は妥当であ るといえる。また, 実験結果に対して計算結果が低く算出

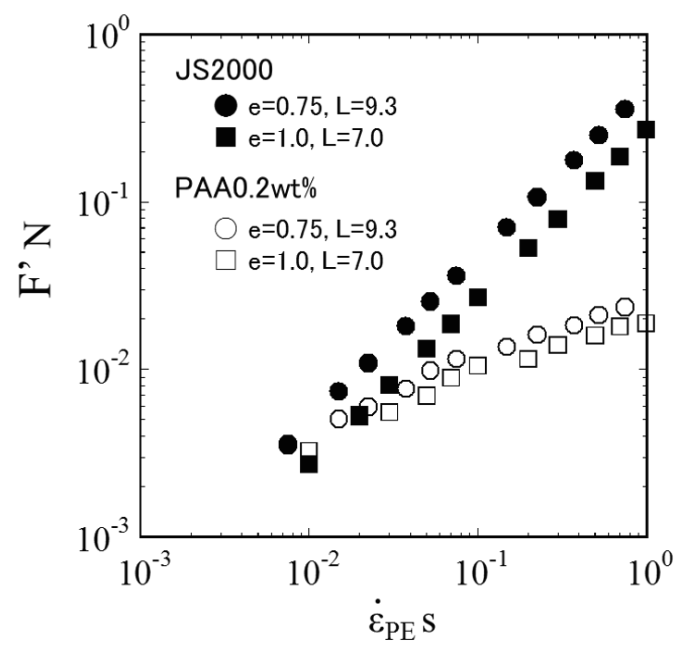

Fig. 7. Buoyancy corrected resistant force $F^{\prime}$ as a function of planar elongation rate.

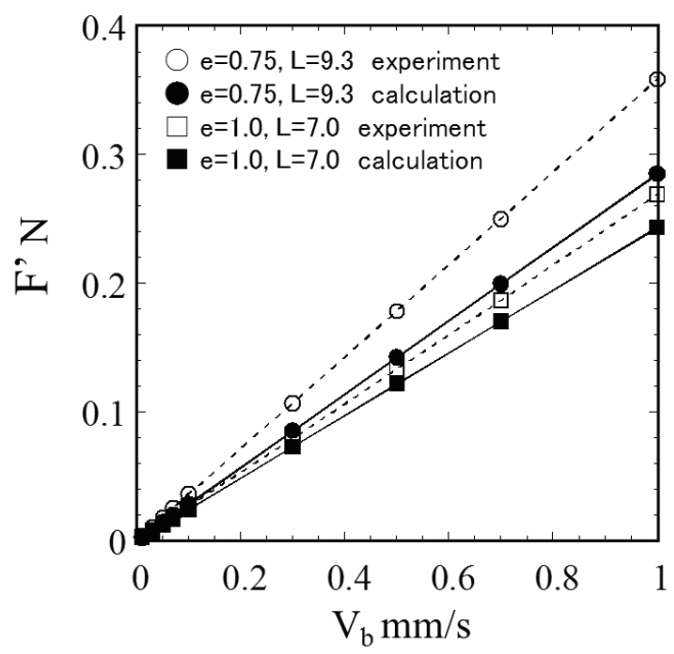

Fig. 8. Comparison of buoyancy corrected resistant force $F^{\prime}$ for JS2000.
されていることがわかる，実験值に対する相対誤差は，全 体を通して，砲弾ボブ $e=0.75$ では $-24 \%, e=1.0$ では $-9 \%$ 程度である。このような差が生じる原因として，まず，隙間 出口における砲弾ボブ側の角で発生した特異点の存在が挙 げられる。特異点は境界条件の不連続性によって生じる問 題であり, 有限要素法では圧力值に乱れが生じる。 そのため, ボブに加わる圧力に誤差が加わったことが指摘される。これ を踏まえ, $e=1$ の流路において Fig. 2(a)の $L_{\text {out }}$ 領域をなくし て特異点を排除した数值解析を行った。その結果を Fig. 9 に 示す。実線と口記号は特異点が存在する計算結果, 実線と $\triangle$ 記号は特異点が存在しない計算結果を表している。この図 より，特異点を排除した計算值は実験值に近づき，相対誤 差は $-3.7 \%$ 程度に減少することがわかる。次に，実際の流 れ場と数值解析に使用した流れ場のボブ壁面せん断速度の 違いが挙げられる。実際の流れ場では砲弾ボブが移動して いるのに対し, 数值解析は砲弾ボブとカップが静止した条 件で行っている，そのため，実際の流れ場はポアズイユ流 れとクエット流れの複合流れ場となり $\dot{\gamma}_{w}$ が増加する。後述 する簡易解析により JS2000の $F^{\prime}$ を算出して比較すると，ボ

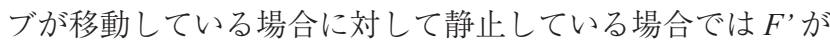
約 $-0.3 \%$ 小さくなる. さらに, 数值解析には砲弾ボブを支 える中心軸を考慮していないことが挙げられる。試料の中 に没している中心軸には壁面に作用するせん断応力によっ て反力が生じる。そのため，ボブを支える中心軸を細くし， 壁面せん断速度および側面積を小さくすることで実験值と 計算值の差を削減できると考えられる.

次に, PAA0.2 wt \% 水溶液の非 Newton 粘性のみを考慮し, 弾性を無視した場合の $F^{\prime}$ の結果を実験結果とともに Fig. 10 に示す。また，粘弾性流動解析より求めた $F^{\prime}$ を Fig. 11 に示 す. Fig. 10 と Fig. 11 より, 両者とも $V_{b}$ の増加に対して $F$, の増加率が減少しており, ずり流動化の挙動を算出できて いる.これは実験結果の傾向と定性的に一致しており，流 動解析における境界条件の設定および反力の計算方法は妥 当であると考えられる。すなわち, 非 Newton 粘性しか考慮 していない計算では，伸張変形による反力の増加は見达ま

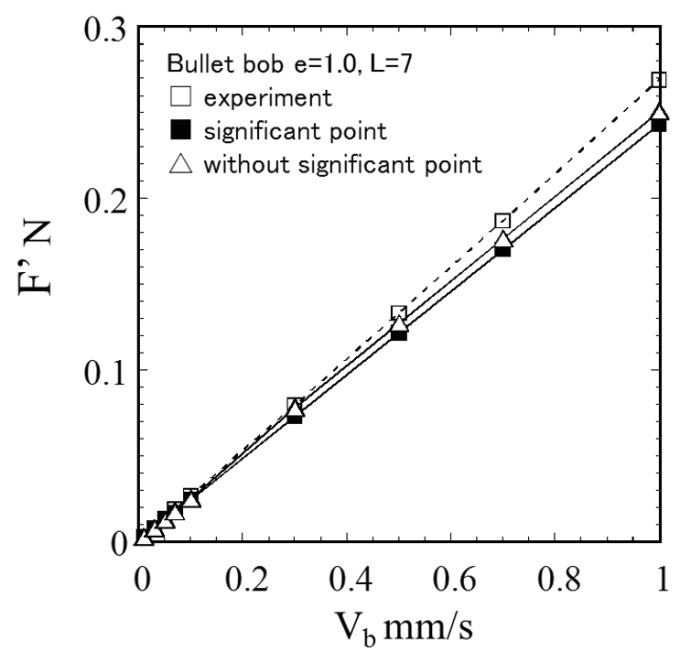

Fig. 9. Comparison of buoyancy corrected resistant force $F^{\prime}$ between significant point and without significant point for JS2000. 
れないために，反力は低めに出ることが考えられる。一方， 粘弾性流体の結果 (Fig. 11) を見ると，計算值の方が実験值よ りも 2.5 倍ほど大きな值となっている. Fig. 12 のせん断速度 分布に注目するとボブとカップの狭い隙間の部分における せん断速度はおおよそ $0.1 \sim 1 \mathrm{~s}^{-1}$ 程度の值を示している。 れは, Fig. 3 の粘度曲線における単一モード Giesekus モデル の粘度は，実測の粘度值よりも大きいことと，弾性応力の 増加に起因した結果と考えられる。しかしながら，弾性応 力はせん断変形による弾性と伸張変形による弾性の和であ り，これらを定量的に分離することは困難である。Fig. 13 に PAA0.2 wt \% 水溶液の流線を示す。この図より, 砲弾ボブと カップの隙間によって構成される流路内にはきれいな流れ が生じており，ボブとカップの隙間に入る流れは，急激に 加速することがわかる. また, Fig. 12 に示す数值解析によ るせん断速度の分布から, 粘弾性流体ではずり流動化によっ

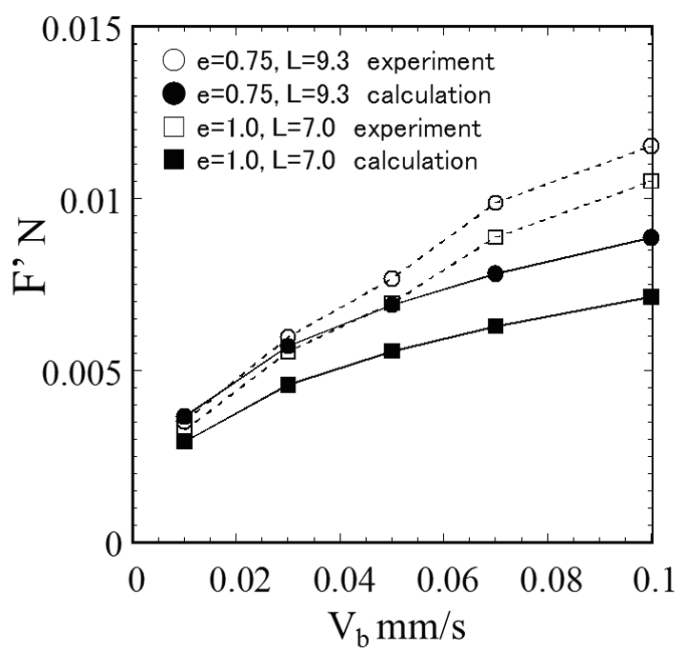

Fig. 10. Comparison of buoyancy corrected resistant force $F^{\prime}$ in PAA0.2 wt $\%$ aqueous solution with non-Newtonian fluid flow analysis.

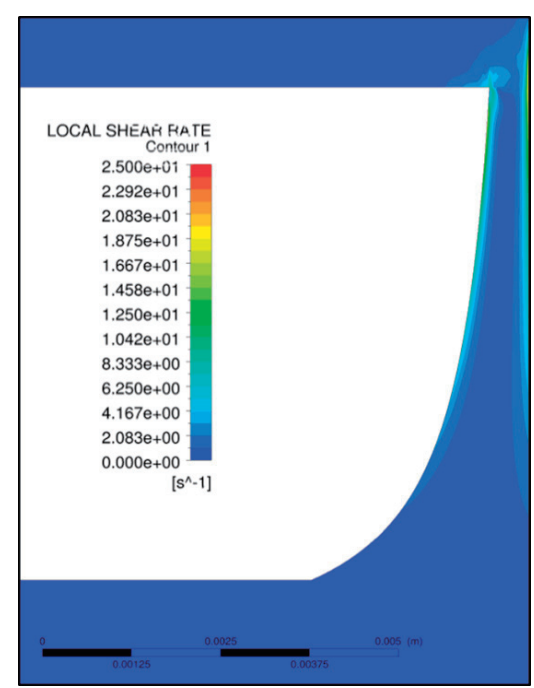

Fig. 12. Shear rate distribution of PAA0.2 $\mathrm{wt} \%$ aqueous solution. Bullet bob $e=1.0$, $L=7.0, V_{b}=0.1 \mathrm{~mm} / \mathrm{s}$.

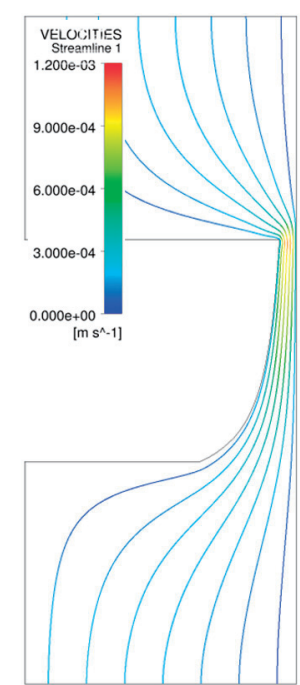

Fig. 13. Streamline of PAA0.2 wt $\%$ aqueous solution. Bullet bob $e=1.0, L=7.0, V_{b}=0.1 \mathrm{~mm} / \mathrm{s}$.
て壁面極近傍のせん断速度が大きな值を示しており，特に 隙間が狭くなる流路出口付近においてこの傾向が顕著に現 れていることが読み取れる。このことから，せん断変形に 伴う弾性の影響は流路出口領域の壁面近傍しか影響を与え ないことがわかった

次に, 流れ場の伸張速度に注目する. Fig. 14 にそれぞれの 試料における砲弾ボブ $e=1.0, \quad V_{b}=0.1 \mathrm{~mm} / \mathrm{s}$ のときの伸張速 度分布を示す。伸張速度は式 (16) より算出した. ${ }^{12}$

$$
\dot{\varepsilon}=3 \mathrm{III}_{d} / \mathrm{II}_{d}
$$

ここに， II ${ }_{\mathrm{d}}$ は変形速度テンソルの第 2 不変量， $\mathbb{I I I}_{\mathrm{d}}$ は変形 速度テンソルの第 3 不変量である。

Fig. 14(a) は Newton 流体の JS2000であり, Fig. 14(b) は PAA0.2 wt $\%$ 水溶液の結果である。試料がカップの液溜り部

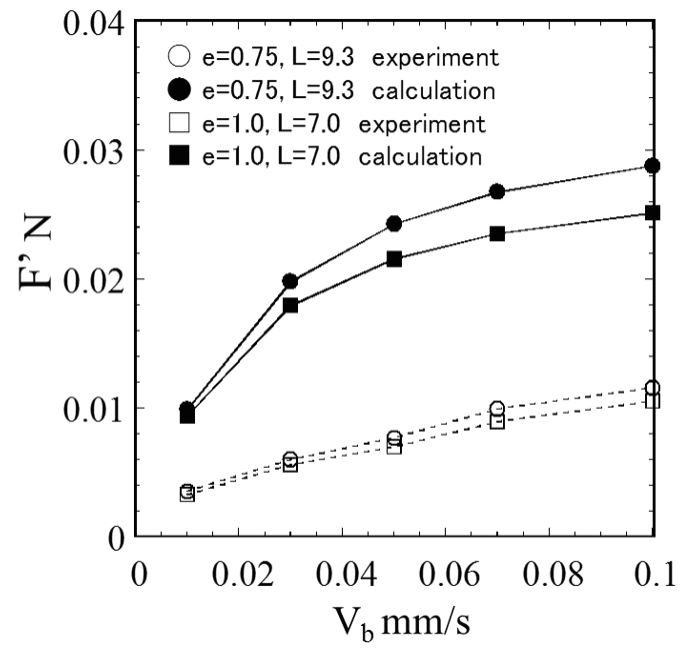

Fig. 11. Comparison of buoyancy corrected resistant force $F$ ' in PAA0.2 wt $\%$ aqueous solution with viscoelastic fluid flow analysis.

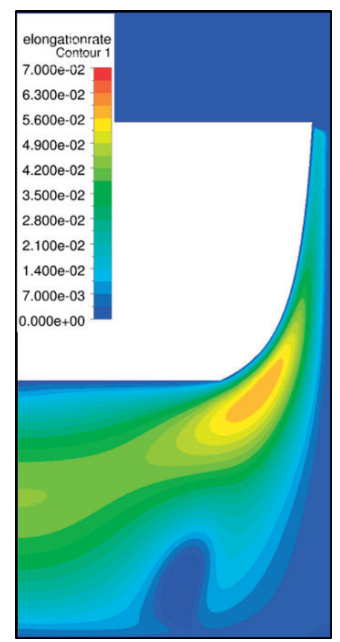

(a) JS2000

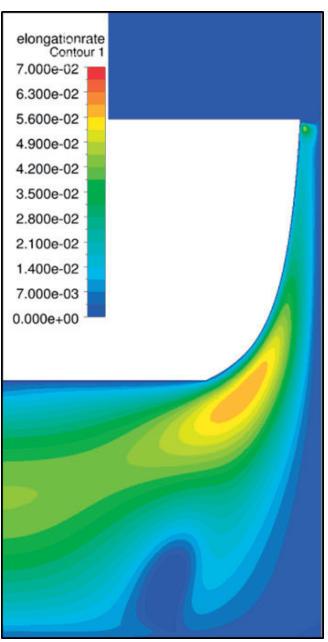

(b) PAA0.2wt $\%$ aqueous solution
Fig. 14. Elongation rate distribution. Bullet bob $e=1.0, L=7.0$, $V_{b}=0.1 \mathrm{~mm} / \mathrm{s}$. 
から隙間へ流入する際に大きな伸張変形が生じることがわ かる. 出口付近のカップ壁面に扔ける伸張速度を比較する と, ずり流動化を示す PAA $0.2 \mathrm{wt} \%$ 水溶液の方がわずかでは あるが伸張速度が大きな領域が広い。 また, 壁面摩擦を考 慮する流れ場では伸張速度の大きさが理想流体と仮定した 設計条件の抒拈よそ $1 / 3$ 程度になるものの, ボブ中央部から 出口にかけての伸張速度は比較的一様な值を示しているこ とがわかる。 これらのことから, 砲弾ボブを用いた手法で は均一な伸張流れ場を得られることが明らかとなった。

\section{3 平面伸張粘度の算出}

砲弾ボブに作用する押し込み反力を簡易的な解析によっ て見積もり, 実験值から平面伸張変形に起因する力を抽出し て平面伸張粘度 $\eta_{P E}$ の算出を行う。代き乗則流体に㧈ける $F$, を簡易的に式(17)で表す.

$$
F^{\prime}=F_{s s}+F_{s n}+F_{P E}
$$

$F_{s s}$ は砲弾ボブ側面に作用するせん断応力による力, $F_{s n}$ は 試料がボブとカップの隙間に扔いてせん断変形する際の粘 性抵抗によりボブ上下に圧力差が生じることで発生する力, $F_{P E}$ は平面伸張応力による力である。 ボブとカップの間の流 れを砲弾ボブの移動を考慮した二次元ポアズイユ流れと仮 定し, Fig. 1(b)に扔ける $z=0, \quad r=R_{b 0}$ を座標原点, そして, 流れ方向を $x$ 軸, 半径方向を $y$ 軸とした直交座標系を適用す ると,コーシーの運動方程式は式 (18)で表される.

$$
0=\left(-\frac{d p}{d x}\right)+\frac{d \tau}{d y}
$$

ベき乗則モデルは式 (19) で示される. ${ }^{13)}$

$$
\tau=K|\dot{\gamma}|^{n-1} \dot{\gamma}
$$

ここに, $K$ は擬塑性粘度, $n$ は構造粘度指数である. 式 (19) を式(18)に代入することにより，ボブ壁面せん断速度 $\dot{\gamma}_{w}$ は 式(20)で与えられる.

$$
\dot{\gamma}_{w}=\left\{\frac{h}{2 K}\left(-\frac{d p}{d x}\right)\right\}^{\frac{1}{n}}+\frac{V_{b}}{h}
$$

ここに, $h$ はカップと砲弾ボブによって構成される隙間の大 きさである、また，圧力こう配は式(21)で与えられる。

$$
\left(-\frac{d p}{d x}\right)=K\left[\frac{2 n+1}{n} \times \frac{V_{b}}{8\left(R_{c}+R_{b}\right)} \times\left(\frac{2}{h}\right)^{\frac{2 n+1}{n}} \times\left\{\left(R_{b 0}+R_{b L}\right)^{2}+2 h\left(R_{c}+R_{b}\right)\right\}\right]^{n}
$$

したがって, $F_{s s}$ は式(22)で示される.

$$
F_{s s}=\int_{0}^{L} \tau \times 2 \pi R_{b} d x=\int_{0}^{L} K \dot{\gamma}_{w}{ }^{n} \times 2 \pi R_{b} d x
$$

また， $F_{s n}$ は圧力こう配を隙間の入口から出口に渡って積分 することにより式(23)で表すことができる。

$$
F_{s n}=\int_{0}^{L}\left(-\frac{d p}{d x}\right) d x \times \pi R_{b L}^{2}=\Delta P_{s} \times \pi R_{b L}^{2}
$$

ニュートン流体の平面伸張粘度はせん断粘度の 4 倍となる ことが知られている。 そこで，心゙き乗則流体に执いてもこ の関係が成り立つと仮定して $F_{P E}$ を式(24)により表す。

$$
F_{P E}=\tau_{P E} \times \pi R_{b L}^{2}=\eta_{P E} \times \dot{\varepsilon}_{P E} \times \pi R_{b L}^{2}=4 \eta \times \dot{\varepsilon}_{P E} \times \pi R_{b L}^{2}
$$

Fig. 15 と Fig. 16 に式(17)を用いて簡易的に導いたJS2000 $\left(K=1.313 \mathrm{~Pa} \cdot \mathrm{s}^{\mathrm{n}}, n=1\right)$ 抢よび $\mathrm{PAA} 0.2 \mathrm{wt} \%$ 水溶液 $\left(K=0.809 \mathrm{~Pa} \cdot \mathrm{s}^{\mathrm{n}}\right.$, $n=0.399)$ の $F^{\prime}$ の值を実験值とともに示す．これらの図より 簡易解析結果と実験結果は定性的に一致していることがわ かる. 実験值に対する簡易解析值の相対誤差は JS2000 の砲 弾ボブ $e=0.75$ では約 $-34 \%, e=1.0$ では約 $-33 \%$ である.

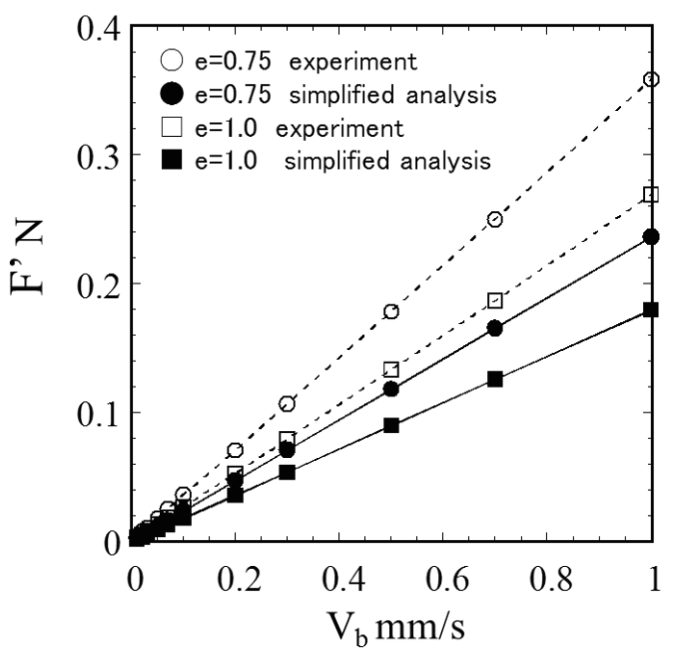

Fig. 15. Comparison of buoyancy corrected resistant force $F^{\prime}$ between experiment and simplified analysis for JS2000.

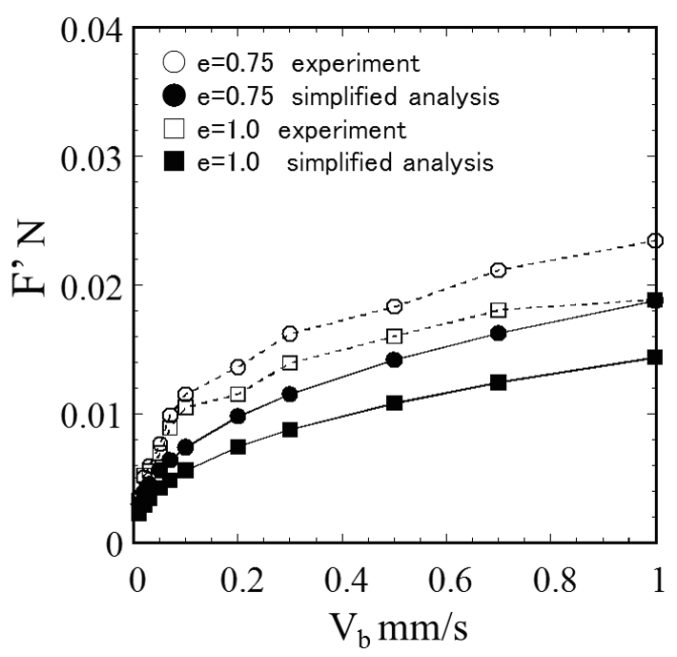

Fig. 16. Comparison of buoyancy corrected resistant force $F$ ' between experiment and simplified analysis for PAA $0.2 \mathrm{wt} \%$ aqueous solution. 


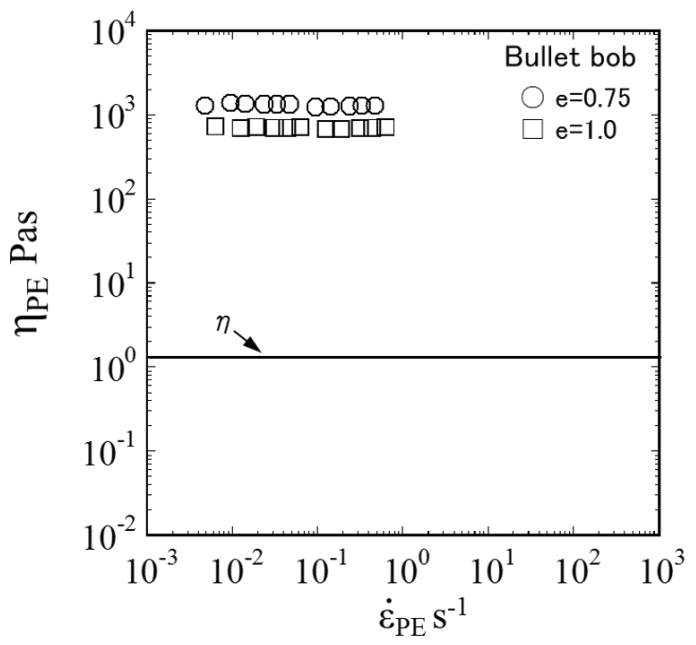

Fig. 17. Planar elongation viscosity of JS2000 measured by the Bullet bob.

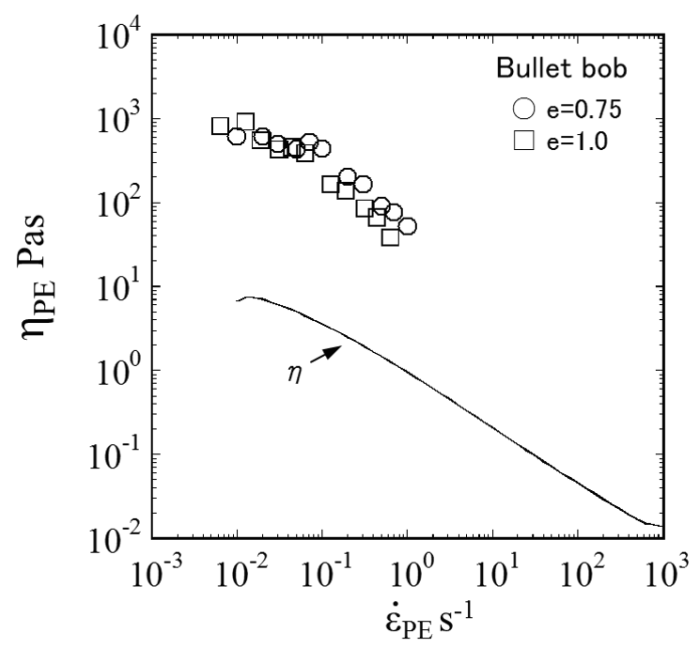

Fig. 18. Planar elongation viscosity of PAA0.2 wt $\%$ aqueous solution measured by the Bullet bob.

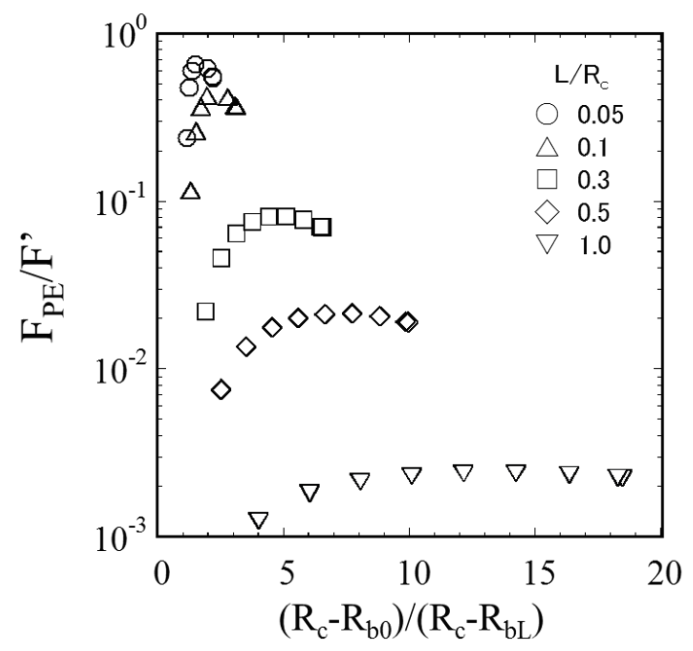

Fig. 19. Optimum bullet bob shape.
また, PAA0 $2 \mathrm{wt} \%$ 水溶液の砲弾ボブ $e=0.75$ では約 $-25 \%$, $e=1.0$ では約 $-37 \%$ である。 このような誤差が生じる原因 として流路入口・出口圧力損失によって生じた反力, および, 砲弾ボブを支える中心軸に作用する反力による影響が考え られる。本研究ではこれらの影響を無視し, 式(25)より $\eta_{P E}$ の算出を行う。

$$
\eta_{P E}=\frac{F_{P E}}{\dot{\varepsilon}_{P E} \times \pi R_{b L}^{2}}=\frac{F_{M}^{\prime}-\left(F_{s s}+F_{s n}\right)}{\dot{\varepsilon}_{P E} \times \pi R_{b L}^{2}}
$$

ここに, $F^{\prime}{ }_{M}$ は浮力の補正を行った押し込み反力の測定值で ある。

Fig. 17 にJS2000の平面伸張粘度 $\eta_{P E}$ の算出結果を示す. この図より， $\eta_{P E}$ は $\dot{\varepsilon}_{P E}$ に依らず一定の值を保つことがわか る. ニュートン流体では $\eta_{P E}$ が変形速度に依存しない定数 であることから，算出結果はこの特性とよく一致している. また, Fig. 18 に PAA0.2 wt \% 水溶液の $\eta_{P E}$ の算出結果を示す. この図より, $\dot{\varepsilon}_{P E}$ の増加に伴って $\eta_{P E}$ が減少する elongationalthinning の傾向が読み取れる。しかしながら, 算出された $\eta_{P E}$ はせん断粘度 $\eta$ の值に対しておおよそ $10^{3}$ 倍大きい值 を示している。この原因として，F'に占める $F_{P E}$ の割合が 非常に小さいことが考えられる。例えば，砲弾ボブ $e=1.0$ を $V_{b}=1.0 \mathrm{~mm} / \mathrm{s}$ でJS2000の満たされたカップに押し込んた 場合, 式 (17) に示すそれぞれの力の大きさは $F_{\mathrm{ss}}=0.014 \mathrm{~N}$, $F_{s n}=0.16 \mathrm{~N}, F_{P E}=0.00067 \mathrm{~N}$ となる. そのため, $F_{P E}$ の大き

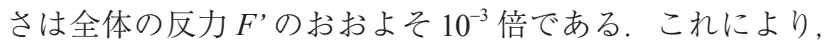
$F^{\prime}$ に対する簡易解析值と実験值の差が数倍であったとして も, 平面伸張粘度に換算すると数百〜数千倍の差となって 表れる。

そこで，全体の反力 $F^{\prime}$ に対して $F_{P E}$ の影響が大きくなる 砲弾ボブの形状を検討する。砲弾ボブ $e=1$ において $R_{c}$ を 一定とした条件で設計を行うことを考える. Fig. 19 の縦軸 は平面伸張応力による力 $F_{P E}$ と押し込み反力 $F^{\prime}$ の比であり, $F_{P E} / F^{\prime}$ が 1 に近いほど全体の反力に占める平面伸張応力の力 の割合が大きいことを示している。また，横軸はボブとカッ プの間の流路における入口と出口の大きさの比であり，1 1 に 近づくほど円筒形状のボブになることを表している. Fig. 19 より $L / R_{c}<0.1$, かつ, この範囲において $\left(R_{c}-R_{b 0}\right) /\left(R_{c}-R_{b L}\right) \doteqdot 1.7$ となる形状にすることにより，せん断流れによる押し达み 反力の影響を削減した平面伸張粘度測定に最適な砲弾ボブ を設計できるといえる.

\section{5. 結言}

本研究では平面伸張粘度の機械的測定法として, 砲弾ボ ブと円筒型カップからなる環状縮小流路を市販の回転型レ オメータに取り付けて押し込み反力を測定し，その反力か ら簡易解析によって平面伸張応力を見積り, 平面伸張粘度 を算出する方法を提案した。 また, 数值解析により砲弾ボ ブのまわりの流れ場を計算し，この手法の正当性について 検討した。以下に得られた結果をまとめる.

JS2000 および PAA0.2 wt \% 水溶液の測定によって得られた 押し込み反力と押し込み速度の関係はそれぞれの試料が有 するニュートン粘性およびずり流動化の特性を示すことが 明らかとなった。数值解析により，ボブとカップ間の流路 
ではせん断変形に伴う弾性の影響は流路出口領域の壁面近 傍に集中すること，また，流路内においてほぼ一様な伸張 速度分布が得られることが示された，簡易解析により算出 された JS2000 およびPAA0.2 wt\% 水溶液の平面伸張粘度は せん断粘度のおおよそ $10^{3}$ 倍大きい值となった。 これは押し 込み反力に対する平面伸張応力に起因した力の大きさが $10^{-3}$ 倍程度の小さな值であり, 測定反力と簡易解析結果の間の 誤差が増幅したためと考えられる. これを踏まえ, 平面伸 張粘度測定に最適な砲弾ボブ形状はカップの半径に対して ボブの長さが $10^{-1}$ 倍以下であり, かつ, 流路入口が出口よ

りも执よそ 1.7 倍大きな形状であることを明らかにした。

\section{REFERENCES}

1) Macosko CW, Ocansey MA, Winter HH, J Non-Newtonian Fluid Mech, 11, 301-316 (1982).

2) Kelly J, Graessley WW, Rheol Acta, 35, 24-38 (1996).

3) Shirakashi M, Takahashi T, Maw WS, Nihon Rheoloji Gakkaishi, 33 (4), 183-190 (2005).
4) Pendse AV, Collier JR, J Appl Polym Sci, 59, 1305-1314 (1996).

5) Takahashi T, Ohiro H, Shirakashi M, Proc XIV Int Congr. on Rheology, Korea (2004), RE26.

6) Kato M, Takahashi T, Shirakashi M, Nihon Rheoloji Gakkaishi, 30 (5), 283-287 (2002).

7) Kato M, Takahashi T, Shirakashi M, Transactions of the JSME series B, 68 (676), 3369-3377 (2002).

8) Yasuda K, et al., Rheol Acta, 20, 163 (1981).

9) Giesekus H, J Non-Newtonian Fluid Mech, 11, 69 (1982).

10) Rajagopalan D, et al., J Non-Newtonian Fluid Mech, 36, 159 (1990).

11) Marchal JM, Crochet MJ, J Non-Newtonian Fluid Mech, 26, 77 (1987).

12) Debbaut B, Crochet MJ, J Non-Newtonian Fluid Mech, 30, 169 (1988).

13) Nakamura K, Non-Newtonian Fluid Mechanics, CORONA PUBLISHING CO., LTD. (1997). 